\title{
Odysseus and the Sirens: A Vision of our Fiscal Future
}

\section{Nicholas Gruen}

$\mathrm{L}$ ast year the Business Council of Australia floated a proposal to re-engineer fiscal policy institutions to make them more like monetary policy institutions (1999). It explored the idea of legislating some capacity to adjust income tax rates (for companies and individuals) across the board at short notice and without further reference to the legislature. Further it floated the idea of an independent body with a degree of control or influence over the new instrument of tax adjustment which was analogous to the control which a central bank has over the conduct of monetary policy.

The BCA paper and its antecedents (Ball, 1996; Gruen, 1997) set out how this might be done. This paper seeks to take things further. After briefly outlining the motivation behind the proposals, the paper moves on to consider and respond to various possible objections.

Certain views about fiscal policy are implicit in the discussion. They can be summarised as follows:

1. Modern democratic politics tends to produce sub-optimal fiscal outcomes. Most commonly this involves a bias towards macro-economic expansion which is both inequitable and inefficient. On occasion, usually following fiscal excess, this tendency is corrected, but that too can result in sub-optimal outcomes - particularly political commitments which have the appearance of fiscal rectitude such as lowering government debt when more meaningful fiscal targets should be pursued such as augmenting net government worth.

2. Active macro-economic management may not always be able to keep the economy at its potential growth optimum. Nevertheless it may sometimes be possible to beneficially 'lean against the wind' of the cycle. One might call this a belief in 'coarse tuning'.

These propositions - both of which are controversial to some degree motivate much of the discussion. If one didn't hold to either of them, there would be little point in the proposals explored here. Nevertheless, the paper is not a contribution to or even a discussion of the theory of optimal fiscal policy. Its subject is how one might improve the political economy of fiscal policy if one believed either of the above propositions. If one was convinced that "coarse tuning' were unwise, one would set up the arrangements proposed here in a way that discouraged such activity.

Nicholas Gruen is an independent economic consultant. 


\section{Modern Fiscal Management: Current Problems and Issues}

\section{The problem of fiscal drift}

Commonsense and experience suggest that contemporary democratic politics exhibit a bias towards fiscal expansion. As the Governor of Australia's Reserve Bank (then Deputy Governor) Ian Macfarlane commented in 1996:

It is easy ... to introduce a new benefit ... But it is difficult to remove existing entitlements because it is always politically unpopular, and there may be large human costs as a result of dependency. This gives a bias towards increasing current expenditure and future levels of taxation, a bias that is readily apparent from the experience of all OECD countries over the past 30 years. (Reserve Bank Bulletin, June, 1996)

Likewise, tax rises are unpopular (and rare). Tax cuts are popular and, the evidence suggests, rather too readily offered by politicians. The combination of these forces is readily apparent in Figure 1.

Figure 1: General Government Financial Balance in OECD Countries

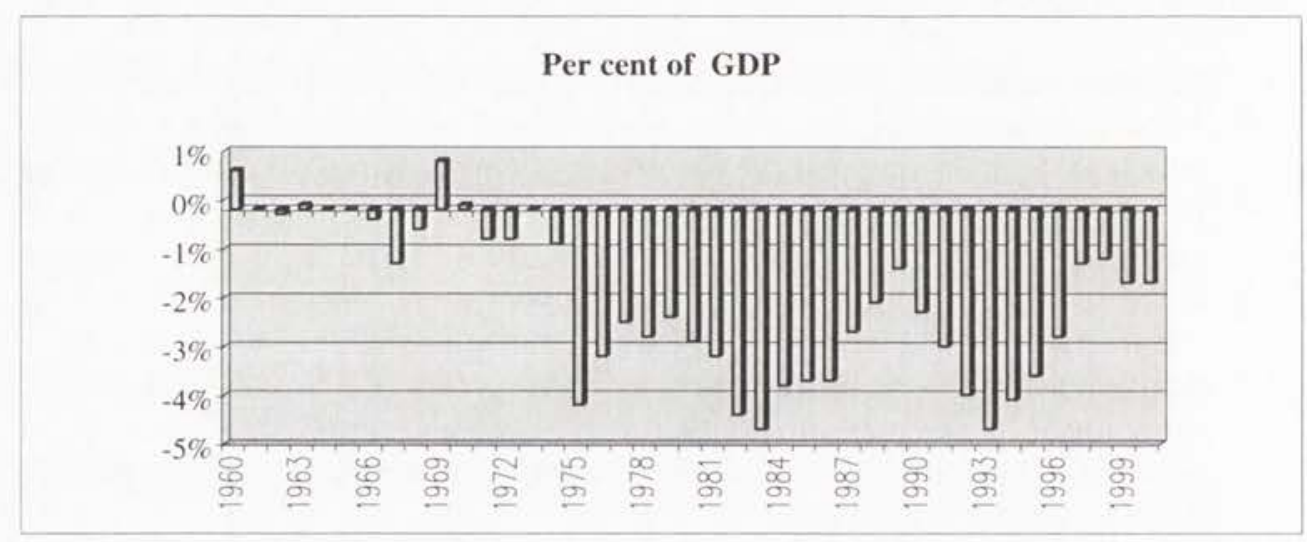

\section{Source: $O E C D$}

Despite the attention given to fiscal consolidation in America, Europe and the antipodes, it seems unlikely that we have conquered fiscal drift. Contemporary evidence suggests that our recent progress has something of the myth of Sisyphus about it. Certainly the last time we rolled the stone to the top of the hill in the late 1980 s we saw it rapidly roll back down once recession struck. The balanced budgets and small surpluses we are now running will be inadequate to 'reload the fiscal cannon' fully for the next downturn. Jeff Kennett's departure from Victorian politics leaving his successors and political opponents with a hefty fiscal 
surplus, some of which is already being spent is also a possible portent that we have reached the highpoint of fiscal responsibility during this cycle. ${ }^{1}$

The friends of fiscal responsibility might ponder what we might do to develop checks and balances to mitigate the ease with which one political party can take advantage of the political sacrifice of its predecessors. If we do not, the political rewards for fiscal responsibility are at risk of further atrophy. The fiscal architecture explored here is not intended as a sketch of a 'brave new world'. In fact the attraction of these ideas lies precisely in the direction in which they offer to develop further existing trends in the contemporary evolution of fiscal policy.

Accordingly the next section explores the way fiscal policy might evolve in such a way as to move closer towards the institutional model of monetary policy set out in the sources cited above. While some of the steps would take more political courage than others, none seem without precedent of one kind or another. As the precedents indicate, none seems politically impossible, and some steps are positively inviting for either governments or oppositions seeking to demonstrate the responsibility necessary to be taken seriously as an alternative government.

\section{Towards More Fiscal Flexibility and Independence}

\section{Extending fiscal transparency}

The first and perhaps most obvious way of beginning to move towards more independent fiscal policy would be further to enhance fiscal transparency by building the independence of our fiscal institutions. Of course we already have important fiscal institutions which have strong independence from executive government - Auditors General. The independence accorded such agencies is the foundation upon which they vouchsafe to fiscal policy what might be called 'micro-integrity' - the integrity of individual transactions, agencies and policies.

Of course simply identifying this as 'micro-integrity' draws attention to the similar importance of 'macro-integrity' - the integrity of the aggregate financial accounts and projections. If we think 'macro-integrity' is of a similar importance as 'micro-integrity', we should develop institutions with a similar degree of independence as those that vouchsafe 'micro-integrity'. In most countries the lead agency for delivering macro-integrity has the status of a department of state.

While the traditions of independence differ, in most OECD countries politicians can, at the very least 'lean' on the senior officers of their departments of state. This compromises the extent to which they can operate as guardians of the integrity of politicians. By contrast, in the United States the Congressional

1 The OECD Economic Outlook was released to delegates during the Senior Budget Officials meeting on 29 May. It showed that despite the assumption of steady growth of 2.8 per cent through 2002 to 2005 , the financial balance would move from 0.3 per cent of OECD GDP in 2002 to $0.1 \%$ of GDP in 2005. Disappointment on the rate of growth, or higher tax cuts than anticipated would vitiate what progress this represents. 
Budget Office prepares a complete set of fiscal and economic forecasts for Congress to be considered alongside those provided by the executive.

Where such institutions do not exist, it is possible that existing interests within a government or its agencies would resist such a development. But the idea can appeal to oppositions. Oppositions are frequently called upon to explain where they will raise the funding to fulfill their promises. So providing they do intend to be fiscally responsible, it suits them to constrain themselves publicly by promising enhanced and independent fiscal macro-integrity measures.

Having promised to do so as Opposition at the last State election, the Victorian Government has now done this by extending the existing role of the Auditor General from reporting on micro-integrity to reporting on macro-integrity. This kind of approach provides the platform for developing fiscal institutions with greater political independence than traditional departments of state. And it does so in a way in which Australia has been repeatedly successful - by developing further the role of an already well-respected institution.

\section{Developing the Instruments}

\section{Minimising lags and broadening the base of fiscal policy}

In many OECD budgets there are opportunities for fiscal consolidation in reducing spending particularly on transfer payments to those who do not need them and in further extending 'user pays' principles. But however worthy or otherwise such measures might be there are limits to the extent to which they provide a systematic foundation for ongoing timely adjustments to the stance of fiscal policy. ${ }^{2}$ As summarised by Ball (1996:12):

Fiscal policy can mean changes in taxes or changes in government spending. For purposes of macroeconomic stabilization, I think changes in taxes are best. Decisions about government spending should be determined by long-run, microeconomic considerations - by whether the benefits of public projects are worth the costs. ${ }^{3}$

We return to this issue below, but let us proceed with Ball's assumption for the moment. We may also note that, at least in principle, the broader the base over which taxes change, the less they need to change to effect any given change in the

\footnotetext{
2 At least in principle, there are opportunities to develop some capacity for fiscal expansion when appropriate by ensuring that public sector infrastructure projects are ready for implementation if suddenly their benefits rise and their opportunity costs fall during an economic downturn. But there are limits to the extent to which this kind of thing can be systematised.

${ }_{3}$ Ball does not address himself to transfer payments here. However transfer payments at least where they are justified by social security considerations and the alleviation of poverty - do not lend themselves well to changes up and down as economic circumstances may require.
} 
fiscal stance. This suggests across the board tax changes. In the 50 s and 60 s, tax driven fiscal policy changes were a commonplace instrument of macro-economic management with 'horror' budgets to tighten and 'give away' budgets to ease.

The use of fiscal policy as one of the arms of macro-economic policy has waned in the last two decades. In Australia such measures became less and less politically feasible for two reasons. First, economically they became more problematic as we failed to 'reload the fiscal cannon' during periods of growth. The fiscal drift which commenced in the mid 1970s threatened fiscal sustainability throwing the focus on medium term fiscal consolidation and structural reform even while the economy was not performing strongly. Second, the conservative dominance of the Senate from the late 1940 s to the mid 1970 s gave way in the late 1970 s to a situation where no government could command a sympathetic majority in the Senate. This had clear implications for the extent to which a government could control taxation.

Nevertheless in the $1960 \mathrm{~s}$ rapid fiscal policy response to emerging developments was one theme of policy discussion. President Kennedy asked Congress for the right to cut taxes at short notice to facilitate rapid fiscal expansion in the event of a future economic slowdown. Today the problem is not so much to ease fiscal policy rapidly as it is to enable fiscal consolidation when appropriate (although that was much less of a problem at the time Kennedy sought the power).

While Kennedy was unsuccessful, institutional infrastructure developed in the United Kingdom takes us half way towards the monetary policy model of fiscal policy. Parliament delegated to the Executive the authority to adjust indirect taxes up and down.

It would not be easy, to introduce such a system into our fiscal policy decision making quickly. It could be misrepresented as an executive grab for power and something that makes tax increases easier. For this reason, the most opportune time to begin progress would be when taxes were being cut in any event. This happens every few years as governments return to the electorate as tax cuts the proceeds of 'fiscal drag', economic growth and any spending restraint they have achieved. In such circumstances it would be possible for a government to cut personal tax rates by an amount it considers to be well within the bounds of prudence. At the same time it could offer further tax cuts that are deliberately offered as a variable 'buffer' and earmarked to be paid and/or taken away as appropriate.

Another circumstance in which progress might be made would be in a situation of temporary fiscal stimulus, as occurred in 1992. The efficacy of temporary fiscal stimulus could be improved where action was taken to entrench community and market expectations that this easing was indeed temporary. The arrangements explored here could provide the appropriate institutional framework for such policies.

Another way of making progress would be long-term targeting such as that which has driven Australia's compulsory superannuation system. Long term targets cannot guarantee undisturbed progress, but they can help focus the 
community and the political process on longer term economic and institutional goals and they can help orient politicians towards long term considerations when they are making their inevitable short term political tradeoffs.

One possible target could be establishing the capacity to raise or lower taxes across the board sufficiently to change revenue by 0.5 per cent of GDP by 2005 and 1 per cent by 2010 . This would create fiscal flexibility but would not of itself increase the degree of fiscal independence. Fiscal independence might actually make the flexibility more attractive. The public might be more disposed to understand small movements in their tax rates (as they do with - even relatively large - changes in interest rates) if they are seen to be strongly influenced by an independent body.

\section{Addressing fiscal drift}

Finally we need some mechanism to deal with the bias towards fiscal drift. Here the lessons from monetary policy seem compelling. In democratic countries monetary and fiscal policy are subject to almost identical problems of political economy. Both can be managed to generate short run gains, with those gains generating long run costs. Where monetary policy is too loose, subsequent generations of voters lose by having to bear the costs of inflation - and/or the more concentrated costs of reducing inflation. Imprudently loose fiscal policy can also impose inflation on future generations but it also lowers government net worth reducing future growth.

Contemporary monetary policy institutions provide some counterweight to the political process. It should be possible to increase the influence of independent policy makers in fiscal policy in a gradual and evolutionary way that builds on existing traditions and developments. The example of the State Government in Victoria has already been cited. If the state government had some control of taxes, as the Government of the United Kingdom did in the 1960s, it would be possible to build the advice of an independent fiscal agency into their management of this instrument. In the first instance the independent agency might simply be free, or be required, to give the Government advice on the use of the instrument. A further level of constraint would be the requirement that the advice to the government be made public. This requirement to receive public advice approximates the level of independence in the setting of tariffs in Australia where the relevant act requires that advice be received from an independent agency before tariff can be changed.

It would take time to get to this stage. It seems ultimately worthwhile to proceed further towards the monetary policy model. How far is of course a matter of opinion. But the extent of formal independence in Australia might be a good place to aim for. Here the Reserve Bank of Australia, is responsible for monetary policy, but consults closely with the government.

It is a matter of controversy as to how much independence is best. Australia's Reserve Bank sets the stance of monetary policy but can be overruled by the Government providing this is done publicly. While much policy discussion 
has tended to assume that 'more independence is better than less', there are potential advantages in a half way house.

Although there can be public differences of view between Government and the Bank, the Government's ability to overrule the Bank tends to ultimately co-opt it into basic support for the Bank's monetary policy. And by the same token, it draws the Bank into attempting to manage monetary policy in a way that takes some account of the politics of the day. The power to overrule the bank publicly has never been used.

In a very thoughtful contribution to debate set off by the BCA discussion paper, the Secretary of the Australian Treasury Mr Ted Evans (2000) offers this defence of an independence forged in collaboration:

[W] hile it would be expected that Board members be apolitical - in the party-political sense - it would equally be expected that they have political abilities: ie that they be adept at assessing facts and taking policy decisions in the national interest. This, together with the requirement of integrity, is the basis of selecting Board members. This latter point appears to have been lost on some who see it as a weakness that the RBA Board is not comprised solely of experts in monetary matters. I think it is fair to say that, at least at this stage of Australia's economic development, monetary policy has become independent partly because the Bank Board is not so comprised.

\section{Some Concerns}

In the following section we respond to some possible objections to the arrangements being proposed.

\section{Won't fiscal transparency legislation help?}

In the last decade both fiscal responsibility and fiscal transparency have made progress together. This is taken by some to indicate that fiscal transparency can be a powerful force for fiscal responsibility. Yet it seems more likely that the same thing has driven each these joint developments - concern about the fiscal situation percolating its way down to the populace. Presumably the disciplines of fiscal transparency have helped. Yet as former New Zealand Finance Minister Ruth Richardson has conceded (1994), fiscal transparency legislation 'places an onus on the government to be explicit about its fiscal strategy, but is neutral as to what that fiscal stance might be'.

Most if not all of the most substantial fiscal blowouts in recent history were relatively transparent to the public. Far from going unreported, fiscal deterioration since the 1970 s was a major topic of policy debate and discussion throughout the years during which it occurred - particularly during the most egregious episodes. 


\section{What about spending?}

Does one want to drive fiscal policy with tax or spending changes? Laurence Ball's position has already been quoted. Most spending - and so spending changes - should be driven by medium to long-term assessments of the costbenefit of different spending options. In theory this seems reasonable. But we should not forget the importance of the urgent in driving fiscal responsibility. Long overdue fiscal tightening often involving spending reductions is often driven by economic and budgetary crises. Without this urgency, spending reductions that are otherwise warranted often do not occur at all.

Our approach in this paper differs somewhat from Ball's. In designing the proposed mechanism, it was thought that across the board spending changes imposed from above involve numerous implementation problems. This does not mean that spending changes should not drive changes in the fiscal stance, only that they would remain at the discretion of the government - with the central fiscal arrangements operating in the background to discipline the government.

The proposed arrangements do not seek to preordain how fiscal policy outcomes should be engineered. They should be seen as a kind of prudential architecture for vouchsafing fiscal prudence and flexibility. Providing they meet the independent authority's standards of fiscal responsibility governments are free to tax and spend as they wish. The new arrangements have the effect that if the authority considers that a change in fiscal policy is required, and the government does not wish to accommodate them, pressure is brought to bear in the first instance to change tax rates. The government can always respond by addressing the authority's concern with a different mix of spending and tax changes than those, which would ultimately be delivered by the prudential architecture.

\section{Co-ordination between macro-economic instruments}

To optimise their joint effectiveness, fiscal and monetary policy should operate in an integrated fashion. At present, this occurs more by default than by design. In many countries fiscal policy is simply unavailable to share any of the weight of managing the economy and so monetary policy is left as the 'swing instrument' for managing the economy. Worse than this, monetary policy must sometimes 'pick up the pieces' as it were to the extent possible where fiscal policy has been politically driven or otherwise mismanaged.

The proposed arrangements offer the prospect of doing better than this. Broadly speaking there are two choices. One can integrate policy by integrating the management of two separate agencies, or by merging independent monetary and fiscal authorities. Ball (1996) proposes the former approach. Another possibility contemplated in the BCA paper would be for the central bank (with its professional expertise appropriately augmented) to exercise the discretions inherent in the proposal. However, this may be seen as undermining the central bank's current focus on monetary policy. Others have argued that it would place too much power in the hands of one institution. 
Another point can be made here. Where monetary policy is constrained in moderating the cycle, fiscal policy's potential contribution becomes more important. Within large and diverse currency unions, monetary policy will target macro-economic conditions across the currency union, rather than the conditions of particular countries or regions within the union. Fiscal flexibility may be the only kind of macro-economic flexibility open to countries or regions which have economies which are moving asynchronously within a currency union.

\section{Democracy and an Independent Fiscal Stance}

It might be argued that the arrangements for more independent fiscal policy are undemocratic. As Evans (2000) commented 'the BCA proposal is not as radical as it has sometimes been portrayed. It is quite common for parliaments to delegate matters to other bodies; indeed that is the objective of much of the legislation passed by parliaments'. Indeed as we have seen there is little in the ideas explored in this paper that does not have precedents elsewhere within the OECD. A wide range of government bodies and authorities in our society are distanced from but still ultimately accountable to - representative democratic institutions.

The ideas explored here would be incapable of implementation - and nor should they be - without the democratic sanction of legislation. The degree of independence given to any government policy-making body is itself ultimately legislated by Parliament and so accountable to the people. In this sense, as Ian Macfarlane has argued, the issue of 'independence' can best seen as 'a discussion about the optimal degree of delegation, including the circumstances in which the delegation could be withdrawn' (1996).

In this context it must be remembered that the kind of power to be delegated is closely circumscribed. An independent fiscal authority would have none of the kinds of power of the legislature to do any favours or impose specific costs on any section of the community. It could not introduce any new taxes or tax concessions. Politicians would continue to perform their democratic duty of deciding who pays what rate of tax, what concessions there are, how much money is spent and on what, etc.

But an independent body would have an influential role in the management of the total tax take. It would take the entire tax system from existing legislation and, by calibrating that system across the board, have influence over one economic variable which is critical to both long and short run economic performance - the relationship between outlays and revenue. Beyond the fact that that it could deliver better performance, fewer and milder recessions, and lower unemployment, the philosophical justification for fiscal policy independence is analogous to the philosophical justification for monetary policy independence.

The fact that we have an intermediary in the area of monetary policy and do not have one in the area of fiscal policy is a product of the different history of the two institutions rather than differing principles. But it is not hard to appreciate a sound political philosophical justification for some independence in monetary policy management. One political generation's undermining of the value of the 
currency to underwrite an unsustainably high rate of economic growth for itself is not only unfair. It is undemocratic. It represents oppression of the minority.

Protecting the minority from oppression does on occasion require departures from strict representative democracy - most obviously concerning the independence of the judiciary for instance. But such protections from oppression of the minority are, in many senses, things that are necessary to the checks and balances which constitute and protect democracy. They are building blocks of democracy rather than derogations from it.

Clearly if the government of the day set short-term interest rates it would be more democratic in the simple sense but so too would electing the Auditor General or the judges of superior appellate courts. In that light, it does not seem fanciful to say that current protections against debasing the currency in democratic countries are, like property rights, part of the apparatus of checks and balances that underpins democracy and makes it more rather than less secure. Precisely the same could be said of checks and balances against one generation depleting the net worth of the public sector imposing higher taxes and lower living standards on subsequent generations.

\section{Conclusion}

The reforms proposed here would give a flexibility and credibility to fiscal policy that it has not enjoyed since at least the $1960 \mathrm{~s}$. It would provide an additional instrument with which to fight the forces of recessions and of booms when and if they threaten should policy makers consider this worthwhile in the circumstances. Despite the apparent boldness of the ultimate vision for fiscal policy, the steps proposed to get there appear manageable. Some will not be easy. But on the other hand they seem economically and politically well within the bounds of practical policy reform. And those steps make sense in their own right whether or not the final vision is ever reached.

Finally can such reform be made attractive to the politicians who must ultimately legislate it for it to become a reality? Like much reform it depends upon the clarity which reformers bring to the task of articulating the case for change and the interests that might be brought to bear in supporting and opposing change. That the reform was first floated by the BCA bodes well in both regards.

Often politicians come to see that a proposed reform may entail short-term discomfort and risk, but that it is ultimately in their own enlightened self-interest. Indeed, the majority of decisions to implement good policy, such as the introduction of fiscal transparency legislation, are probably in this category. The widespread political support for independence of monetary policy is ultimately underpinned by the fact that most politicians who considered the matter would not want the power back. They recognise it for the poisoned chalice that it is.

The politicians' world is one of short-term drama; one in which grassfires are forever being fought. Introducing constraints to power is always risky. But as the political science literature, commonsense and experience illustrate, recessions are much more than a grassfire for governments. They are one of the surest avenues 
to political disaster and even destruction. Good macro-economic policy provides the best way of avoiding or ameliorating a recession.

Paul Keating used to talk of 'wearing the hair shirt' of a floating exchange rate - allowing the market to pass judgement on the economic policy of the Government each and every day. This was a critical discipline on that government and, despite the plethora of grass-fires which are the stuff of being in government, helped constrain it to stick to the 'straight and narrow' of policies which were broadly acceptable to the market place. And politicians frequently find constraints in their own interest to help them manage political pressures within their own parties. Likewise, today monetary policy independence has become one of the 'hair shirts' that governments wear. Despite its frustrations, it helps them govern well and so preserve their longevity.

Another way of dramatising what is at stake, for politicians, is to contrast the experiences of Australia and New Zealand government over the last four years. The growth path which Australia maintained through the Asian crisis was, to a substantial extent, dependent upon both the independence and the good judgement (or luck) of Australia's Reserve Bank. Without that independence it would have been very hard for the bank to resist the increase in interest rates which the markets were expecting. Independence may not have been sufficient to have avoided a recession during the crisis (witness New Zealand's recession with a similarly independent Reserve), but it could well have been necessary. And avoiding recessions is almost always necessary to staying in government. The Australian Government of 1997 is still with us. The New Zealand Government was swept from office.

Australia's GDP is now an astonishing seven per cent higher than it would have been if it had experienced a recession of the duration and intensity of New Zealand's. That illustrates the size of the economic prize for improvements in macro-economic management. And it also underpins the claim that further fiscal policy reform is well and truly in the enlightened self-interest of politicians with any aspirations for longevity.

Finally, the recent defeat of the Kennett Government in Victoria may well have marked the high point of popular fiscal rectitude in Australia. Governments may be wary of running up large surpluses lest their political opponents manage to reap the rewards of their hard political work. More independent fiscal policy would seem to be in the enlightened self-interest of a government with such concerns.

Having suggested earlier that the lot of the fiscal policy maker today bears an unfortunate resemblance to that of Sisyphus, we may conclude that what we are after is for our political masters to borrow instead from the wily Odysseus. For it was Odysseus who had himself lashed to the mast to overcome the temptation of the sirens. And as we know, in his embrace of self-constraint he saved himself. He lived to fight another day. 


\section{References}

Ball, L. (1996), 'A Proposal for the Next Macro-Economic Reform', mimeo, Victoria University of Wellington Foundation, Wellington.

Business Council of Australia (1999), Avoiding Boom/Bust: Macro-Economic Reform for a Globalised Economy, Melbourne. (http://www.bca.com.au/aboutbcaset.htm)

Evans, E. (2000), 'Some Aspects of Economic Governance', Address to The Sydney Institute, Sydney, 14 March.

Gruen, N. (1997), 'Making Fiscal Policy Flexibly Independent of Government', Agenda 4(3):297-307.

IMF (1999), Code of Good Practice on Fiscal Transparency, Washington DC, (http://www.imf.org/external/np/fad/trans/manual/)

Keech, W. (1995), Economic Politics: The Costs of Democracy, Cambridge University Press, Cambridge.

Macfarlane, I. (1996), 'Making Monetary Policy: Perceptions and Reality', Paper presented to 25th Conference of Economists, Canberra, 25 September.

Reserve Bank of Australia, Reserve Bank Bulletin, various issues.

Richardson, R. (1994), 'Comment on the Fiscal Responsibility Bill', Public Sector $17(1): 10-11$.

This paper is an edited version of a paper presented by Nicholas Gruen at the Annual Meeting of Senior Budget Officials at the OECD in Paris on 29 May 2000. The views expressed in the paper are those of the author and should not be attributed to any other person or organisation. The author acknowledges the detailed comments of an anonymous referee that helped improve the paper. 